\title{
Release of Ceramide after Membrane Sphingomyelin Hydrolysis Decreases the Basolateral Secretion of Triacylglycerol and Apolipoprotein B in Cultured Human Intestinal Cells
}

\author{
F. Jeffrey Field, Heshun Chen, Ella Born, Brad Dixon, and Satya Mathur \\ Department of Internal Medicine, University of Iowa; and the Veterans Administration, Iowa City, Iowa 52242
}

\begin{abstract}
The effect of sphingomyelin hydrolysis on triacylglycerol-rich lipoprotein secretion was examined in the human intestinal cell line, $\mathrm{CaCo}-2$. Addition of sphingomyelinase decreased sphingomyelin and phosphatidylethanolamine by 60 and $20 \%$, respectively. Sphingomyelin hydrolysis decreased the basolateral secretion of triacylglycerol mass, newly synthesized triacylglycerol, and apo B mass. Pulse-chase experiments with $\left.{ }^{35} \mathrm{~S}\right]$ methionine demonstrated a decrease in apo $B$ synthesis and a marked decrease in apo B100 and apo B48 secretion without altering apo A1 secretion. Sphingomyelin hydrolysis did not change apo $B$ mRNA levels nor apo $B$ turnover. Phosphatidylcholine-specific phospholipase $C$ did not decrease apo $B$ synthesis or its basolateral secretion. Membrane protein kinase C (PKC) activity was decreased twofold after sphingomyelin hydrolysis. The PKC inhibitor staurosporine decreased apo B mass and newly synthesized apo B secretion. Sphingomyelinase and staurosporine together caused an additional decrease in apo B secretion suggesting that sphingomyelin hydrolysis decreased apo $B$ secretion independently of its effect on PKC activity. Moreover, conditions that increase PKC activity did not increase apo $B$ secretion. Cell-permeable analogs of ceramide decreased immunoreactive apo B secretion. Sphingosine was without effect. The hydrolysis of membrane sphingomyelin by intestinal or pancreatic neutral sphingomyelinase may lead to the accumulation of cellular ceramide, which, in turn, could inhibit triacylglycerol-rich lipoprotein secretion. ( $J$. Clin. Invest. 1993. 92:2609-2619) Key words: sphingomyelin • sphingosine $\bullet$ protein kinase $\mathrm{C} \bullet$ apo $\mathrm{B} \bullet \mathrm{CaCo}-2$ cells
\end{abstract}

\section{Introduction}

There is a recognized relationship between the two lipids sphingomyelin and cholesterol. Both lipids occupy similar cellular compartments (1). Sphingomyelin and cholesterol increase concomitantly within cells during aging, neoplastic transformation, and in atherosclerosis (2-4). The sphingomyelin content of a membrane influences the movement and distribution of cholesterol within and among membranes (5). It has been suggested that sphingomyelin has a molecular attraction or affinity for cholesterol that traps or solubilizes the sterol within the membrane. The close relationship of both lipids also ex-

Address correspondence to F. Jeffrey Field, Div. of GastroenterologyHepatology, Department of Internal Medicine, University of Iowa Hospitals, Iowa City, IA 52242.

Received for publication 4 January 1993 and in revised form 11 June 1993.

The Journal of Clinical Investigation, Inc.

Volume 92, December 1993, 2609-2619 tends to their metabolism. Slotte and Bierman (6) and Gupta and Rudney (7) found that after the hydrolysis of membrane sphingomyelin, cholesterol is released from the plasma membrane. The cholesterol then enters intracellular pools, leading to alterations in the rate of synthesis and esterification of the sterol. Moreover, in the genetically inherited syndrome of Niemann-Pick disease, the accumulation of sphingomyelin within cells results in the disruption of normal cholesterol trafficking and metabolism (8-10).

Evidence has been accumulating that supports a role for sphingomyelin metabolism in the signal transduction pathway (for review see references 11,12 ). Both sphingosine and ceramide, products of sphingomyelin hydrolysis, have been implicated as biological effectors of cell function $(13,14)$. Sphingosine is a potent inhibitor of protein kinase $C(P K C)^{1}$ activity in vitro as well as in cell culture (13). In GH3 cells, for example, membrane sphingomyelin hydrolysis leads to the suppression of PKC activity (15). This suggests that sphingomyelin catabolism can alter cell function by the liberation of sphingosine or ceramide from the cell membrane. It is likely that membranebound neutral sphingomyelinase plays an important role in the hydrolysis of plasma membrane sphingomyelin and hence, in the initiation of the signal transduction pathway.

Our laboratory has recently demonstrated the existence of neutral sphingomyelinase activity in human pancreatic juice, human small intestine, and in $\mathrm{CaCo}-2$ cells (16). Moreover, it was observed that after sphingomyelin hydrolysis of $\mathrm{CaCo}-2$ cell membranes, less cholesterol mass was secreted basolaterally. Thus, in intestinal absorptive cells, changes in sphingomyelin metabolism, with its associated changes in cholesterol metabolism and release of biological effectors, could lead to alterations in the assembly and/or secretion of triacylglycerolrich lipoprotein particles. The present study was performed to investigate if sphingomyelin hydrolysis interfered with triacylglycerol transport by $\mathrm{CaCo}-2$ cells. The results of this study demonstrate that sphingomyelin hydrolysis causes a decrease in the basolateral secretion of triacylglycerol and apo B by $\mathrm{CaCo}-2$ cells as well as a decrease in membrane $\mathrm{PKC}$ activity. It is postulated that, independent of its effect on PKC activity, the hydrolysis of intestinal membrane sphingomyelin causes the release of ceramide which accumulates within cells and interferes with apo B secretion.

\section{Methods}

Materials. $\left[9,10-{ }^{3} \mathrm{H}\right]$ oleic acid, $\left[\gamma_{-}{ }^{32} \mathrm{P}\right] \mathrm{ATP}$ and $\left[\alpha^{-32} \mathrm{P}\right] \mathrm{dCTP}$ were purchased from New England Nuclear (Boston, MA). Trans $-\left[{ }^{35} \mathrm{~S}\right]-$ methionine $(1100 \mathrm{Ci} / \mathrm{nmol})$ was obtained from ICN Radiochemicals

1. Abbreviations used in this paper: $\mathrm{C}_{2}$-Cer, $N$-acetylsphingosine; $\mathrm{C}_{6}-$ $\mathrm{Cer}, \mathrm{N}$-Hexanoylsphingosine; PKC, protein kinase $\mathrm{C}$. 
(Irvine, CA ). Oleic acid, fatty acid poor bovine serum albumin, triglyceride analysis kit, salmon sperm, dextran sulfate, prestained gel electrophoresis standards (molecular mass range 25-180 kD), octadecylamine, sphingomyelin, sphingomyelinase, phosphatidylcholine-specific phospholipase $\mathrm{C}$, staurosporine, monoolein, taurocholate, Histone IIIs, $4 \beta$-phorbol 12-myristate 13-acetate (PMA), and Triton $\mathrm{X}-100$ were purchased from Sigma Chem. Co. (St. Louis, MO). $N$-Hexanoylsphingosine $\left(\mathrm{C}_{6}\right.$-Cer $)$ and $N$-acetylsphingosine $\left(\mathrm{C}_{2}\right.$-Cer $)$ were obtained from Matreya, Inc. (Chalfont, PA). Rabbit polyclonal antibody ( IgG fraction) specific for apo B was purchased from Calbiochem (San Diego, CA). Protein A bound to sepharose was from Repligen Corp. (Cambridge, MA). Apo B, apo B monoclonal antibody (clone 1607) (IgG2b fraction purified by column chromatography), apo AI monoclonal antibody, and apo B sheep immunopurified polyclonal antibody conjugated to horseradish peroxidase were from BIODESIGN International (Kennebunkport, ME). Bovine phosphatidylserine was purchased from Avanti Polar Lipids (Pelham, AL). DEAE Sephacel was obtained from Pharmacia LKB Biotechnology Inc. (Piscataway, NJ). Rabbit sera containing antibody to human apo AI was provided by Dr. Dennis Black, Department of Pediatrics, University of Chicago, Chicago, IL. TMB Microwell Peroxidase Substrate System was purchased from Kirkegaard \& Perry Labs., Inc. (Gaithersburg, MD). 96-well Nunc-Immuno plates were from VWR Scientific Corp. (Batavia, IL). A human apo $B$ cDNA probe ( $6 \mathrm{~kb}$ long and spanning a region complementary to exon 26 of the apo B gene) inserted into a $2.1-\mathrm{kb}$ plasmid PGEM 3 was used for dot-blot hybridization. The plasmid was digested with BAMH1 and the apo B cDNA insert purified by agarose gel electrophoresis using standard techniques. An human muscle actin cDNA probe was provided by Dr. Peter Rubenstein, Department of Biochemistry, University of Iowa. All other reagents were reagent grade.

Cell culture. CaCo-2 cells were cultured in 24-well plastic dishes (Costar Corp., Cambridge, MA) or on polycarbonate semipermeable membranes separating an upper and lower well as described $(17,18)$.

Measurement of lipid synthesis. The rates of cholesteryl ester, triglyceride, and phospholipid synthesis within cells and that secreted into the basolateral medium were determined as previously described (17).

Apo B and ceramide mass. Apo B mass within cells and that secreted into the basolateral medium were estimated by sandwich ELISA as described (18). Ceramide was estimated using diacylglycerol kinase as described by Preiss et al. (19). The ceramide phosphates were separated on silica gel G plates (Fisher Scientific, Pittsburgh, PA) using solvent system chloroform/acetone/methanol/acetic acid/water (10/ $4 / 2 / 2 / 1)(20)$. The ${ }^{32} \mathrm{P}$-radiolabeled bands were visualized by autoradiography and the band corresponding to ceramide was counted in Budget Solve (Research Products International Corp., Elk Grove Village, IL) by liquid scintillation spectroscopy. The ${ }^{32} \mathrm{P}$-labeled ceramide phosphates made from $0,50,100,250$, and 500 pmol of $\mathrm{C}_{6}$-Cer (Matreya, Inc.) were used as standards to quantitate the amount of ceramide present within cells.

Apo B and apo Al synthesis and degradation. $\mathrm{CaCo}-2$ cells were cultured on $6.5 \mathrm{~mm}$ Transwell inserts (Costar Corp., Cambridge, MA). On day 14, the cells were washed with M199 and incubated for $16 \mathrm{~h}$ in M199 medium containing $1 \mathrm{mM}$ oleic acid attached to $330 \mu \mathrm{M}$ albumin in the presence or absence of $100 \mathrm{mU} / \mathrm{ml}$ sphingomyelinase. The next morning the cells were washed and preincubated for $1 \mathrm{~h}$ with methionine-free M199. The cells were then pulsed for $2 \mathrm{~h}$ with $100 \mu \mathrm{Ci}$ of $\left[{ }^{35} \mathrm{~S}\right]$ methionine $/ 100 \mu \mathrm{l}$ of methionine-free medium. At the end of the incubation, the medium was removed and the cells were solubilized in $100 \mu \mathrm{l}$ of ice-cold cell lysis buffer ( $10 \mathrm{mM}$ Na phosphate, $\mathrm{pH} 7.5$, containing $5 \mathrm{mM}$ EDTA, $5 \mathrm{mM}$ EGTA, $100 \mathrm{mM} \mathrm{NaCl}, 1 \%$ (vol/vol) Triton X-100, $0.1 \%$ SDS, $0.5 \%$ (wt/vol) Na deoxycholate, $1 \mathrm{mM}$ PMSF, $20 \mu \mathrm{M}$ leupeptin, $1 \mathrm{mM}$ DTT, $1 \mathrm{mM}$ methionine, and $0.1 \mathrm{mM}$ cysteine). The cell extract was transferred to a 1.5-ml Eppendorf tube. The filter was rinsed with $100 \mu \mathrm{l}$ of the cell lysis buffer. The two extracts were combined and made to $1 \mathrm{ml}$ with cell lysis buffer and sonicated for $10 \mathrm{~s}$. The basal medium was diluted to $1 \mathrm{ml}$ with cell lysis buffer and transferred to a 1.5-ml Eppendorf tube. Samples of the cell extract and the medium were taken for estimation of TCA-precipitable radioactiv- ity incorporated into total proteins. A portion of the cell extract was also taken for protein determination.

To estimate apo AI and apo B degradation, cells were pulsed for 30 min with $200 \mu \mathrm{Ci}$ of $\left[{ }^{35} \mathrm{~S}\right]$ methionine. The inserts were transferred to a new 24-well plate containing $0.6 \mathrm{ml}$ of $\mathrm{M} 199,1 \mathrm{mM}$ methionine, and $0.1 \mathrm{mM}$ cysteine. The cells were then incubated in M199 containing 1 $\mathrm{mM}$ methionine and $0.1 \mathrm{mM}$ cysteine with or without the treatment as described in the figure legends. At the indicated time, the cells were harvested in $0.2 \mathrm{ml}$ of cell lysis buffer. The cell homogenate and basal medium were analyzed as described above for estimation of synthesis.

Immunoprecipitation of apo B and AI. Aliquots from cell and basolateral medium containing similar amounts of TCA-precipitable counts $\left(\sim 5 \times 10^{6}\right)$ were precleared of nonspecific counts by incubation with $0.05 \mathrm{ml}$ of protein A attached to Sepharose (binding capacity, $4 \mathrm{mg}$ human $\mathrm{IgG} / \mathrm{ml}$ ) on a tube rocker for $1 \mathrm{~h}$ at $4^{\circ} \mathrm{C}$. This was followed by centrifugation for $10 \mathrm{~min}$ at $13,000 \mathrm{~g}$ in a refrigerated microfuge. To the supernatant was added rabbit immunopurified polyclonal antibody directed against human apo B or AI. The amount of antibody used was in excess as estimated by repeating the immunoprecipitation on the supernatant from the first immunoprecipitation. The samples were incubated for $18 \mathrm{~h}$ at $4^{\circ} \mathrm{C}$ in a rocker. The antigen-antibody complexes were precipitated with $0.05 \mathrm{ml}$ of protein A bound to Sepharose. The samples were rocked for $1 \mathrm{~h}$ and centrifuged for $30 \mathrm{~s}$ at 13,000 $g$. The pellet containing the antigen-antibody complex bound to protein A was washed six times with $1 \mathrm{ml}$ of cell lysis buffer and once with $1 \mathrm{ml}$ of phosphate-buffered saline. The washed pellet was taken up in $0.04 \mathrm{ml}$ of $1 \times$ Laemmli sample buffer and the proteins were separated on $5 \%$ stacking and $8 \%$ separating porous gels as described by Doucet et al. (21). After electrophoresis, the gels were treated with fixative solution ( $5 \%$ methanol, $7 \%$ acetic acid) for $30 \mathrm{~min}$, washed three times with distilled water, and soaked for $30 \mathrm{~min}$ at room temperature in $1 \mathrm{M}$ sodium salicylate. The gels were dried at $80^{\circ} \mathrm{C}$ for $2 \mathrm{~h}$ and the radioactive bands were detected by exposing the gels to Kodak X-Omat AR film for $48-72 \mathrm{~h}$. The radioactivity from gel portions corresponding to apo B100, apo B48, and apo AI bands was determined by liquid scintillation.

Apo B mRNA estimation. After incubating CaCo-2 cells for $16 \mathrm{~h}$ with $100 \mathrm{mU} / \mathrm{ml}$ of sphingomyelinase, RNA was extracted from the cells with acid guanidium isothiocyanate/phenol/chloroform mixture as described by Chomczynski and Sacchi (22). 1-8 $\mu$ g of total RNA was applied to nylon membrane filters (Nytran; Midwest Scientific, Valley Park, MO) via dot-blot apparatus. The filters were dried at $80^{\circ} \mathrm{C}$ in a vacuum oven. Prehybridization was performed at $42^{\circ} \mathrm{C}$ for $2 \mathrm{~h}$ in buffer containing $20 \mathrm{ml}$ formamide, $2 \mathrm{ml}$ of $20 \%$ SDS, $0.4 \mathrm{ml}$ of salmon sperm $(10 \mathrm{mg} / \mathrm{ml})$, and $7.4 \mathrm{ml}$ of diethylpyrocarbonate water. After labeling the respective cDNA probes by random priming (23), duplicate filters were hybridized with either ${ }^{32} \mathrm{P}$-apo $\mathrm{B}$ cDNA or ${ }^{32} \mathrm{P}$ - $\alpha$-actin cDNA. The filters were washed twice for $15 \mathrm{~min}$ at room temperature in $6 \times$ SSPE and $0.1 \%$ SDS, once at $42^{\circ} \mathrm{C}$ for $30 \mathrm{~min}$ in $1 \times$ SSPE and $0.1 \%$ SDS, and once at $65^{\circ} \mathrm{C}$ for $45 \mathrm{~min}$ in $1 \times$ SSPE and $0.1 \%$ SDS. The filters were exposed to $x$-ray film with intensifying screens for $24-48 \mathrm{~h}$. mRNA abundance for apo B and $\alpha$-actin were quantitated by laser densitometry of the autoradiograms. The densities of apo B mRNA were normalized to the densities of $\alpha$-actin mRNA.

$P K C$ activity. After the incubation described in the figure legend, cells were washed three times with phosphate buffered saline and placed on ice. Cells from three to four wells were scraped into $500 \mu \mathrm{l}$ of PKC homogenization buffer ( $20 \mathrm{mM}$ Tris- $\mathrm{HCl}, 3 \mathrm{mM}$ EGTA, $50 \mathrm{mM}$ 2-mercaptoethanol, $\mathrm{pH}$ 7.5). Separation of cytosolic and particulate fractions and assay for PKC activity were performed as previously described with minor modifications (24). All procedures were conducted at $4^{\circ} \mathrm{C}$. Briefly, the homogenate was sonicated twice for $15 \mathrm{~s}$ (lowest output of a Branson sonicator; Branson Ultrasonics Corp., Danbury, CT) and then centrifuged at $500 \mathrm{~g}$ for $10 \mathrm{~min}$. The supernatant was removed and centrifuged at $100,000 \mathrm{~g}$ for $30 \mathrm{~min}$ (L8-M ultracentrifuge in T-875 fixed angle rotor; Beckman Instruments, Inc., Fullerton, CA). The supernatant (cytosolic fraction) was aspirated and the pellet was extracted with $500 \mu \mathrm{l}$ of PKC homogenization buffer containing 
$0.2 \%$ Triton $\mathrm{X}-100$ and centrifuged at $100,000 \mathrm{~g}$ for $30 \mathrm{~min}$. The supernatant (membrane fraction) was used without further purification to measure PKC activity. PKC activity in the cytosolic fraction was either measured directly or after further chromatography on DEAE Sephacel. For DEAE chromatography, the cytosolic fraction was applied to a $1-\mathrm{ml}$ column of DEAE Sephacel then washed with $4 \mathrm{ml}$ of homogenization buffer followed by elution of PKC into $2 \mathrm{ml}$ of homogenization buffer containing $0.1 \mathrm{M} \mathrm{NaCl}$.

PKC activity was assayed by measuring the phosphorylation of histone IIIs. The assay was performed by adding $10-20 \mu$ l of the cytosolic or membrane fraction (0.5-3 $\mu \mathrm{g}$ protein/tube) to the reaction buffer (final concentration: $50 \mathrm{mM}$ Tris- $\mathrm{HCl}, \mathrm{pH} 7.5,12.5 \mathrm{mM} \mathrm{MgCl}_{2}, 0.5$ $\mu \mathrm{g} / \mathrm{ml}$ histone IIIs, $27.8 \mu \mathrm{M}$ ATP, $0.5 \mu \mathrm{Ci} /$ tube of $\left[\gamma-{ }^{32} \mathrm{P}\right] \mathrm{ATP}$ in the presence or absence of the PKC activators $60 \mu \mathrm{M}$ phosphatidylserine, $4.4 \mu \mathrm{M}$ PMA and $7 \mathrm{mM} \mathrm{CaCl}_{2}$ in a final volume of $90 \mu \mathrm{l}$ ) and incubating at $30^{\circ} \mathrm{C}$ before terminating the assay with $10 \mu \mathrm{l}$ of $75 \mathrm{mM}$ phosphoric acid and placing on ice. The ${ }^{32} \mathrm{P}$ incorporated into histone was determined by spotting $75 \mu$ l of each sample onto $2 \mathrm{~cm}^{2}$ of P-81 paper (Whatman, Inc., Clifton, $\mathrm{NJ}$ ) and the unreacted $\left[\gamma-{ }^{32} \mathrm{P}\right] \mathrm{ATP}$ removed by washing four times for 10 min each in $400 \mathrm{ml}$ of $75 \mathrm{mM}$ phosphoric acid. The paper was rinsed in ethyl alcohol and then dried. The samples were cut out and quantitated by liquid scintillation counting. Background counts were less than $0.1 \%$ of total counts. PKC activity was determined as the difference between the kinase activity measured in the presence and absence of phosphatidylserine, PMA, and calcium.

Cell viability. Viability of cells grown on semipermeable membranes was evaluated by trypan blue exclusion and by measuring the release of cellular lactate dehydrogenase (LDH) (18). Sphingomyelinase had no effect on cell viability as determined by these parameters.

Chemical analysis. Protein was measured according to the method of Bradford (25) or Lowry et al. (26). Triglyceride mass was measured as previously described (27). Phospholipid mass was estimated by the method described by Chalvardjian and Rudnicki (28).

\section{Results}

Phospholipid mass. Table I shows the phospholipid content remaining in $\mathrm{CaCo}-2$ cells after a 16-h incubation with 100 $\mathrm{mU} / \mathrm{ml}$ of sphingomyelinase. In control cells, sphingomyelin constituted $\sim 10 \%$ of the total phospholipids. After incubating with sphingomyelinase, $60 \%$ of the sphingomyelin was depleted. The amount of phosphatidylcholine remaining in cells after sphingomyelin hydrolysis was unchanged from controls. Similar results were obtained when labeled choline was used to estimate the amounts of phosphatidylcholine and sphingomyelin remaining in cells after treatment with this concentration of sphingomyelinase (16). In cells incubated with sphingomyelinase, phosphatidylethanolamine mass was also decreased ( $P$ $<0.05)$. In another experiment, in which cells were first steady state labeled with $\left[{ }^{3} \mathrm{H}\right.$ ] ethanolamine before their incubation with sphingomyelinase, a $20 \%$ decrease in phosphatidylethanolamine after sphingomyelin hydrolysis was confirmed (data not shown).

Triacylglycerol transport. To address the effect of sphingomyelin hydrolysis on newly synthesized triacylglycerol transport, $\mathrm{CaCo}-2$ cells were grown on semipermeable micropore filters separating an upper and lower chamber. After a 2-h preincubation with $100 \mathrm{mU} / \mathrm{ml}$ of exogenous sphingomyelinase added to the apical medium, the cells were incubated for 1 , 2 , and $4 \mathrm{~h}$ with $25 \mu \mathrm{M}$ of labeled oleate solubilized in a micelle containing $1 \mathrm{mM}$ taurocholate and $50 \mu \mathrm{M}$ cholesterol. The rate of incorporation of labeled oleate into cellular lipids and lipids secreted into the basolateral medium was determined. The results are shown in Fig. 1. The rates of synthesis of cellular triacylglycerol and phospholipid were not altered by sphingo-
Table I. Effect of Sphingomyelinase on Phospholipid Mass

\begin{tabular}{lcc}
\hline & Control & Sphingomyelinase \\
\hline & \multicolumn{2}{c}{ nmol/mg protein } \\
Total phospholipids & $192 \pm 10$ & $166 \pm 6$ \\
Phosphatidylcholine & $83 \pm 9$ & $73 \pm 6$ \\
Phosphatidylinositol & $15 \pm 1$ & $13 \pm 1$ \\
Phosphatidylethanolamine & $65 \pm 3$ & $52 \pm 3^{\ddagger}$ \\
Sphingomyelin & $21 \pm 1$ & $8 \pm 1^{*}$ \\
\hline
\end{tabular}

CaCo-2 cells, cultured on 24-well plastic dishes, were incubated for 16 $\mathrm{h}$ with $100 \mathrm{mU} / \mathrm{ml}$ of sphingomyelinase. After the incubation, lipids were extracted from the cells and the phospholipids were separated by thin-layer chromatography. Phospholipid mass was estimated as described in Methods. ${ }^{*} P<0.001, n=6 .{ }^{\ddagger} P<0.05, n=6$.

myelinase. Compared to control cells, however, the rate of oleate incorporation into cholesteryl esters was significantly increased by sphingomyelin hydrolysis. The secretion of newly synthesized triacylglycerol into the basolateral medium by cells incubated with sphingomyelinase was markedly decreased. At $4 \mathrm{~h}$, cells incubated with sphingomyelinase contained twofold more labeled cholesteryl esters than control cells; and yet, the amount of labeled cholesteryl esters secreted into the basolateral medium by these cells was less than control. At 1 and $2 \mathrm{~h}$, more labeled phospholipids were secreted into the basolateral medium by cells incubated with sphingomyelinase. At $4 \mathrm{~h}$, however, this effect was no longer present.

To address the effect of sphingomyelin hydrolysis on the transport of triacylglycerol mass, $\mathrm{CaCo}-2$ cells were incubated for $4 \mathrm{~h}$ with $1 \mathrm{mM}$ oleic acid attached to albumin (3:1, mol:mol) and $100 \mathrm{mU} / \mathrm{ml}$ of active sphingomyelinase or sphingomyelinase that had been inactivated by heating for 10 min at $80^{\circ} \mathrm{C}$. The amount of triacylglycerol mass that accumulated in the basolateral well was then estimated. Compared to control cells, cells incubated with active sphingomyelinase secreted 2.3-fold less triacylglycerol mass into the basolateral well $(5.5 \pm 0.3$ vs $12.5 \pm 0.6 \mu \mathrm{g} /$ well, $P<0.001)$. Thus, the hydrolysis of apical membrane sphingomyelin decreased the transport of both newly synthesized triacylglycerols and triacylglycerol mass by $\mathrm{CaCo}-2$ cells.

Apo $B$ mass. A decrease in the secretion of triacylglycerol mass by $\mathrm{CaCo}-2$ cells suggests that either fewer lipoprotein particles are being secreted or less triacylglycerol is being carried per lipoprotein particle. To investigate if sphingomyelin hydrolysis caused a decrease in the number of lipoprotein particles being secreted by $\mathrm{CaCo}-2$ cells, apo $\mathrm{B}$ mass within cells and apo B secreted into the basolateral medium were estimated by ELISA. CaCo-2 cells were incubated for $16 \mathrm{~h}$ with increasing concentrations of sphingomyelinase (Fig. $2 \mathrm{~A}$ ). Compared to control cells, there was a concentration-dependent decrease in the amount of apo B secreted into the basolateral medium by cells incubated with sphingomyelinase. In a similar experiment, triacylglycerol-rich lipoprotein production was induced by incubating cells for $16 \mathrm{~h}$ with $1 \mathrm{mM}$ oleic acid attached to albumin with or without $100 \mathrm{mU} / \mathrm{ml}$ sphingomyelinase. The results are shown in Fig. $2 \mathrm{~B}$. Under experimental conditions of increased lipoprotein assembly and secretion, sphingomyelin hydrolysis caused a $50 \%$ decrease in the amount of apo B secreted into the basolateral medium. 


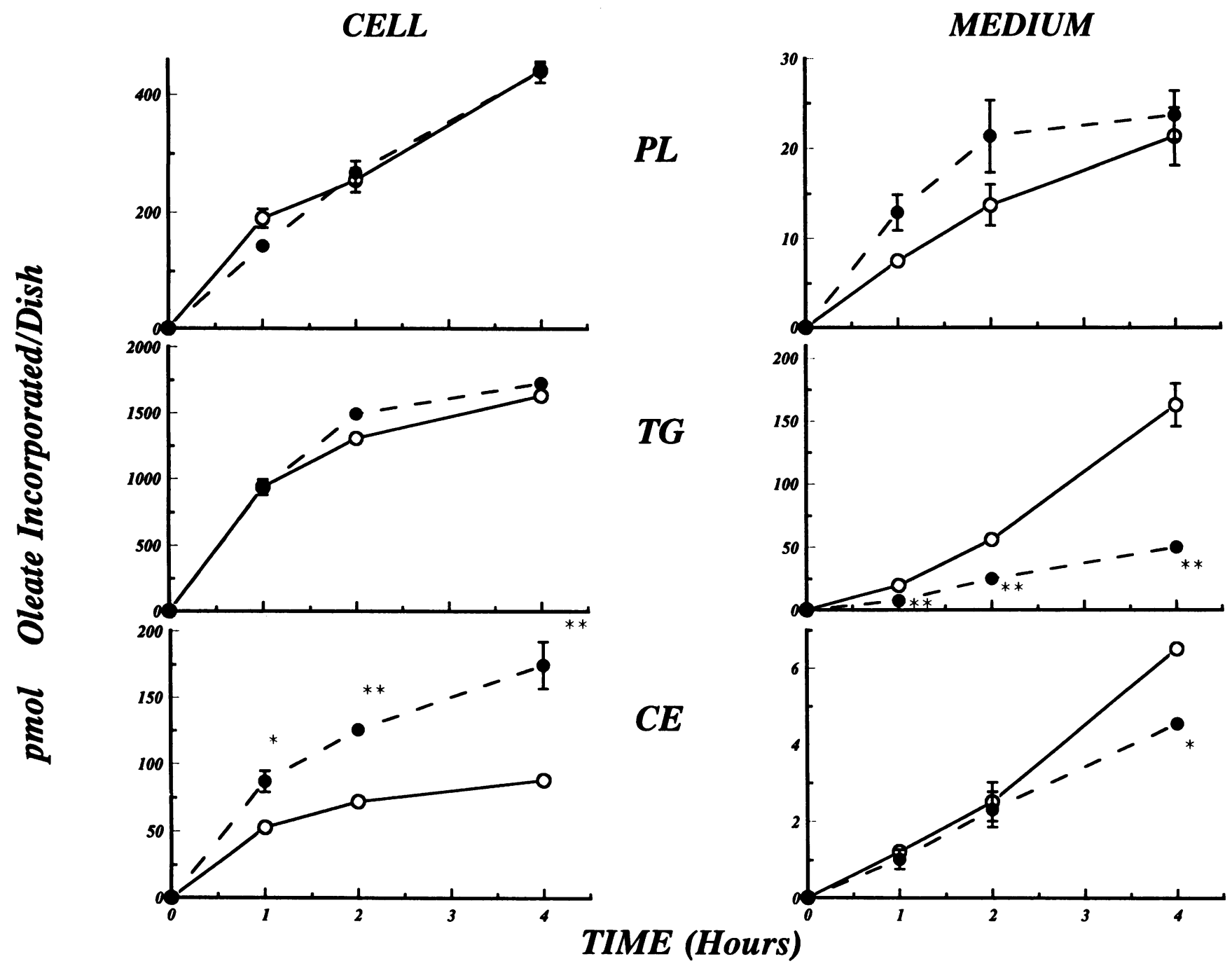

Figure 1. Effect of sphingomyelin hydrolysis on the incorporation of $\left[{ }^{3} \mathrm{H}\right]$ oleate into cellular and basolaterally secreted lipids. CaCo-2 cells were cultured for $14 \mathrm{~d}$ on semipermeable polycarbonate filters separating an upper and lower well. On the day of the experiment, the cells were washed twice in M199 and incubated for $2 \mathrm{~h}$ in M199 containing $100 \mathrm{mU} / \mathrm{ml}$ of sphingomyelinase in the apical medium. The apical medium was then replaced with M199 containing $1 \mathrm{mM}$ taurocholate, $50 \mu \mathrm{M}$ cholesterol, and $25 \mu \mathrm{M}\left[{ }^{3} \mathrm{H}\right]$ oleate, specific activity $1,100 \mathrm{dpm} / \mathrm{pmol}$. Sphingomyelinase was added to the apical media of cells that had it originally. At the indicated times, lipids were extracted from the cells and the basolateral media, separated by thin-layer chromatography, and the bands corresponding to phospholipids, triacylglycerols, and cholesteryl esters were scraped and counted. The data represent the means $\pm \mathrm{SE}$ of three individual dishes at each time point. The absence of error bars indicate that the error is less than the data point itself. $\circ$, control; $\bullet$, sphingomyelinase. ${ }^{*} P<0.05$ vs control. ${ }^{* *} P<0.01$ vs control.

The effect of sphingomyelin hydrolysis on apo B secretion was reversible. After incubating with sphingomyelinase, $\mathrm{CaCo}-$ 2 cells were allowed to recover by incubating them for $5 \mathrm{~h}$ in growth medium containing $20 \%$ FCS. The cells were then incubated for $16 \mathrm{~h}$ with $1 \mathrm{mM}$ oleic acid attached to albumin. The amount of apo B secreted into the basolateral medium by cells that were first incubated with sphingomyelinase was no different from controls (data not shown).

Apo $B$ and apo AI synthesis and degradation. To address the effect of sphingomyelin hydrolysis on apo B and apo AI synthesis, CaCo-2 cells were incubated for $16 \mathrm{~h}$ with $1 \mathrm{mM}$ oleic acid with or without sphingomyelinase. The next morning, after a $1-h$ preincubation in methionine-free medium, the cells were pulsed for $2 \mathrm{~h}$ with $\left[{ }^{35} \mathrm{~S}\right]$ methionine. At the times indicated in Fig. 3, $A$ and $B$, apo B and apo AI were immunoprecipitated from the cells and basolateral medium and the immunoprecipitates separated by polyacrylamide gel electro- phoresis. In cells incubated with sphingomyelinase, the synthesis of apo B100 and apo B48 was significantly decreased (cell plus medium data). Apo AI synthesis was also decreased after sphingomyelin hydrolysis, but the decrease was less than that observed for either apo B100 or apo B48. Total protein synthesis, as estimated by the incorporation of $\left[{ }^{35} \mathrm{~S}\right]$ methionine into TCA-precipitable protein, was not altered (data not shown).

The predominant effect of sphingomyelin hydrolysis, however, was observed in the secretion of newly synthesized apo B. Compared to control cells, cells incubated with sphingomyelinase secreted significantly less labeled apo B100 and apo B48. In contrast, sphingomyelin hydrolysis had no significant effect on the secretion of labeled apo AI or total TCA-precipitable proteins.

In liver cells, early intracellular degradation of apo B has been postulated to regulate the amount of apo B secreted (29, 30). To investigate if sphingomyelinase altered the turnover 

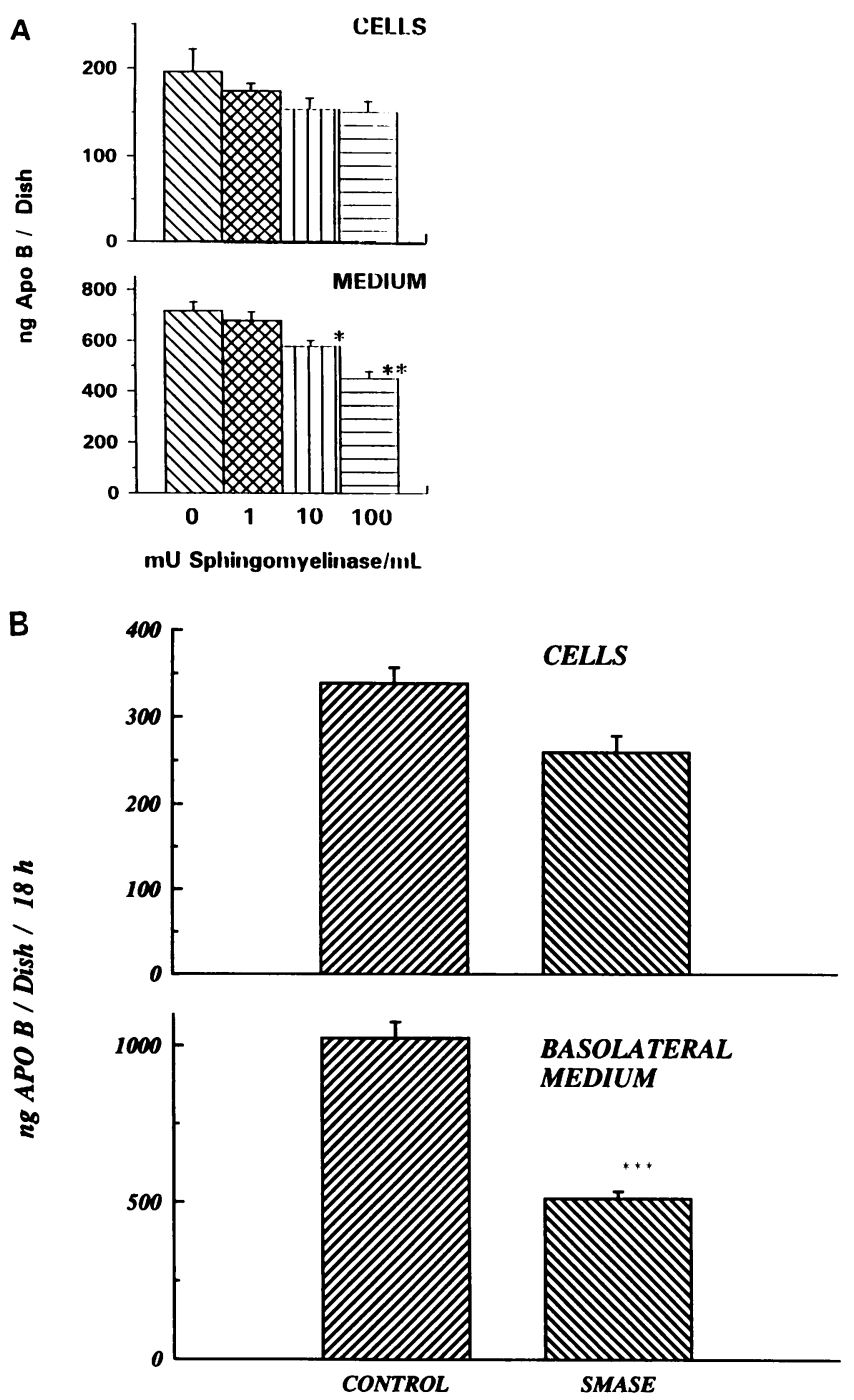

Figure 2. Effect of sphingomyelin hydrolysis on apo B mass. CaCo-2 cells were cultured as described in Fig. 1. $(A)$ The cells were washed twice in M199, placed in new wells, and incubated for $16 \mathrm{~h}$ in M199 containing increasing concentrations of sphingomyelinase. $(B)$ The cells were washed twice in M199, placed in new wells, and incubated for $16 \mathrm{~h}$ in M199 containing $1 \mathrm{mM}$ oleic acid-albumin (3:1, mol/ mol) with or without $100 \mathrm{mU} / \mathrm{ml}$ sphingomyelinase (SMASE). Apo $\mathrm{B}$ mass was estimated within cells and in the basolateral medium as described in Methods. $(A) n=6$ dishes at each concentration with ELISA done in triplicate. $(B) n=12 .{ }^{*} P<0.05$ vs control. ${ }^{* *} P$ $<0.01$ vs control. ${ }^{* * *} P<0.001$ vs control.

rate of apo $\mathrm{B}, \mathrm{CaCo}-2$ cells were again incubated for $16 \mathrm{~h}$ with 1 $\mathrm{mM}$ oleic acid in the presence or absence of $100 \mathrm{mU} / \mathrm{ml}$ of sphingomyelinase. The next morning, after a 1-h preincubation in methionine-free medium, cells were pulsed for $30 \mathrm{~min}$ with $200 \mu \mathrm{Ci}$ of $\left[{ }^{35} \mathrm{~S}\right.$ ] methionine. After the pulse, the cells were washed, placed in new wells, and chased for $3 \mathrm{~h}$ with excess unlabeled methionine. At different times during the chase, apo $\mathrm{B}$ and apo AI were immunoprecipitated from the cells and basolateral medium and were separated by polyacrylamide gel electrophoresis. Fig. 4 shows the autoradiogram of the gel $(A)$, and the amount of radioactivity recovered from the bands $(B)$. It is again clear from the autoradiogram that in cells incubated with sphingomyelinase there was a significant decrease in the
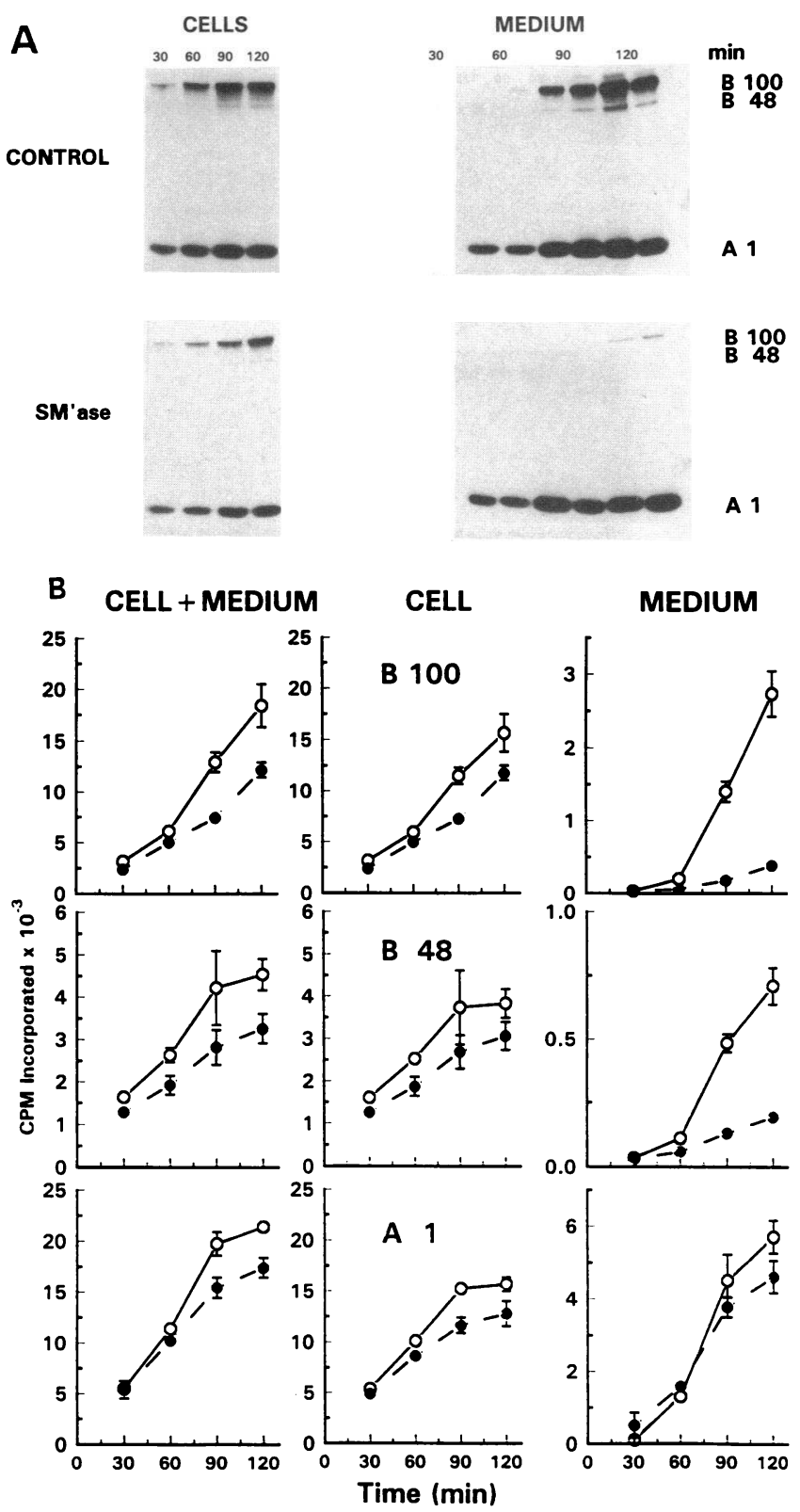

Figure 3. Effect of sphingomyelin hydrolysis on the incorporation of $\left[{ }^{35} \mathrm{~S}\right]$ methionine into apo B and apo AI. CaCo-2 cells were incubated for $16 \mathrm{~h}$ in M199 containing $1 \mathrm{mM}$ oleic acid attached to albumin $(3: 1, \mathrm{~mol} / \mathrm{mol})$ with or without $100 \mathrm{mU} / \mathrm{ml}$ of sphingomyelinase (SM'ase). The cells were washed twice and incubated for $1 \mathrm{~h}$ in methionine-free medium. $\left[{ }^{35} \mathrm{~S}\right]$ Methionine, $100 \mu \mathrm{Ci}$, was added for 2 $\mathrm{h}$ and at the indicated times, apo B and apo AI were immunoprecipitated from the cells and basolateral media. The apoproteins were separated by SDS polyacrylamide gel electrophoresis. $(A)$ This figure is an autoradiogram of a representative gel. $(B)$ Radioactivity data recovered from the apo B100, apo B48, and apo AI bands of the gel. $\mathrm{O}$, control; •, sphingomyelinase.

appearance of labeled apo B100 and apo B48 in the basolateral medium. In contrast, apo AI secretion was not significantly altered. Although initial radioactivity in apo B100 and apo B48 was less in cells after sphingomyelin hydrolysis (as expected from the synthesis data), the rates of turnover for apo B100, apo B48 and apo AI were not significantly different from controls. 
A

CELLS

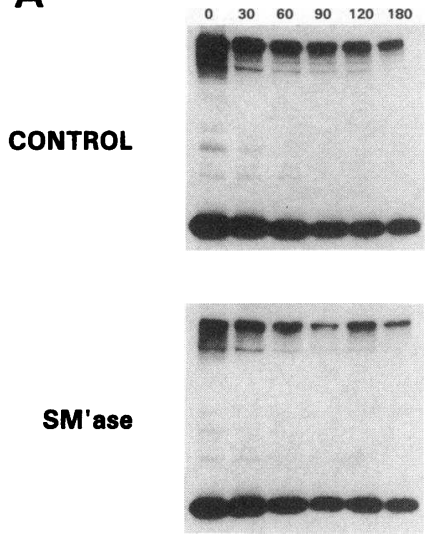

B

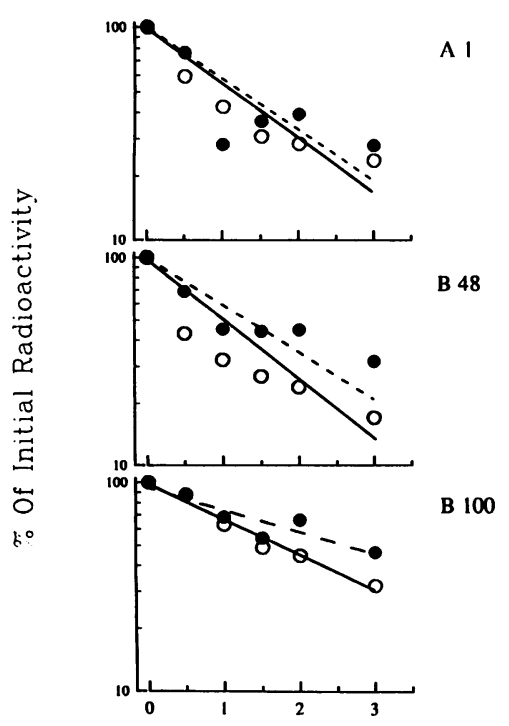

MEDIUM

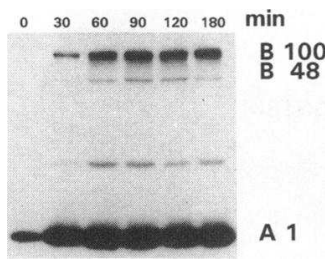

B 100

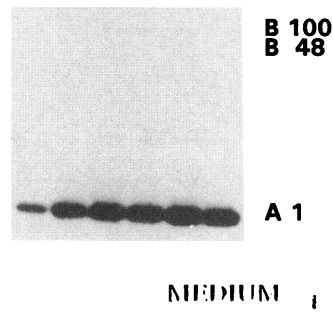

TIME (Hours)

Figure 4. Effect of sphingomyelin hydrolysis on the turnover of $\left[{ }^{35} \mathrm{~S}\right]-$ methionine-labeled apo B and apo AI. The cells were incubated as described in Fig. 3. After a 1-h preincubation in methionine-free medium, the cells were pulsed for $30 \mathrm{~min}$ with $200 \mu \mathrm{Ci}$ of $\left[{ }^{35} \mathrm{~S}\right]$ methionine. The apical and basolateral media were removed and replaced with media containing $10 \mathrm{mM}$ methionine and $1 \mathrm{mM}$ cysteine. At the indicated times into the chase, apo B and apo AI were immunoprecipitated from the cells and basolateral media. The apoproteins were separated by SDS polyacrylamide gel electrophoresis. This figure shows a representative autoradiogram $(A)$ and the amount of radioactivity recovered from each of the bands $(B)$. $\odot$, control; $\bullet$, sphingomyelinase.

Apo B mRNA. Because sphingomyelin hydrolysis was associated with a decrease in the synthesis of apo $B$, apo $B$ mRNA levels were estimated in $\mathrm{CaCo}-2$ cells incubated for $16 \mathrm{~h}$ with 1 $\mathrm{mM}$ oleic acid in the presence or absence of sphingomyelinase. The amount of apo B mRNA in control cells and cells incubated with sphingomyelinase was similar (data not shown).

Phospholipase C. Sphingomyelinase is a phospholipase C enzyme cleaving phosphocholine from the sphingomyelin molecule. To address the specificity of the hydrolysis of the sphingomyelin molecule on apo B secretion, the effect on apo B synthesis and secretion by the hydrolysis of the other cholinecontaining phospholipid, phosphatidylcholine, by phosphatidylcholine-specific phospholipase $\mathrm{C}$, was investigated. Phosphatidylcholine phospholipase $\mathrm{C}, 200 \mathrm{mU} / \mathrm{ml}$, hydrolyzed $15 \%$ of cellular phosphatidylcholine or $12.5 \mathrm{nmol}$ (compared to the hydrolysis of $1.7 \mathrm{nmol}$ of sphingomyelin by sphingomyelinase) without altering the cellular content of other phospholipids. Data in Fig. 5 show the effect of this phospholipase C on the incorporation of $\left[{ }^{35} \mathrm{~S}\right]$ methionine into apo $\mathrm{B}$ and apo AI and their secretion into the basolateral medium. In contrast to the effect of sphingomyelin hydrolysis (Fig. 3), the hydrolysis of phosphatidylcholine resulted in a modest increase in the
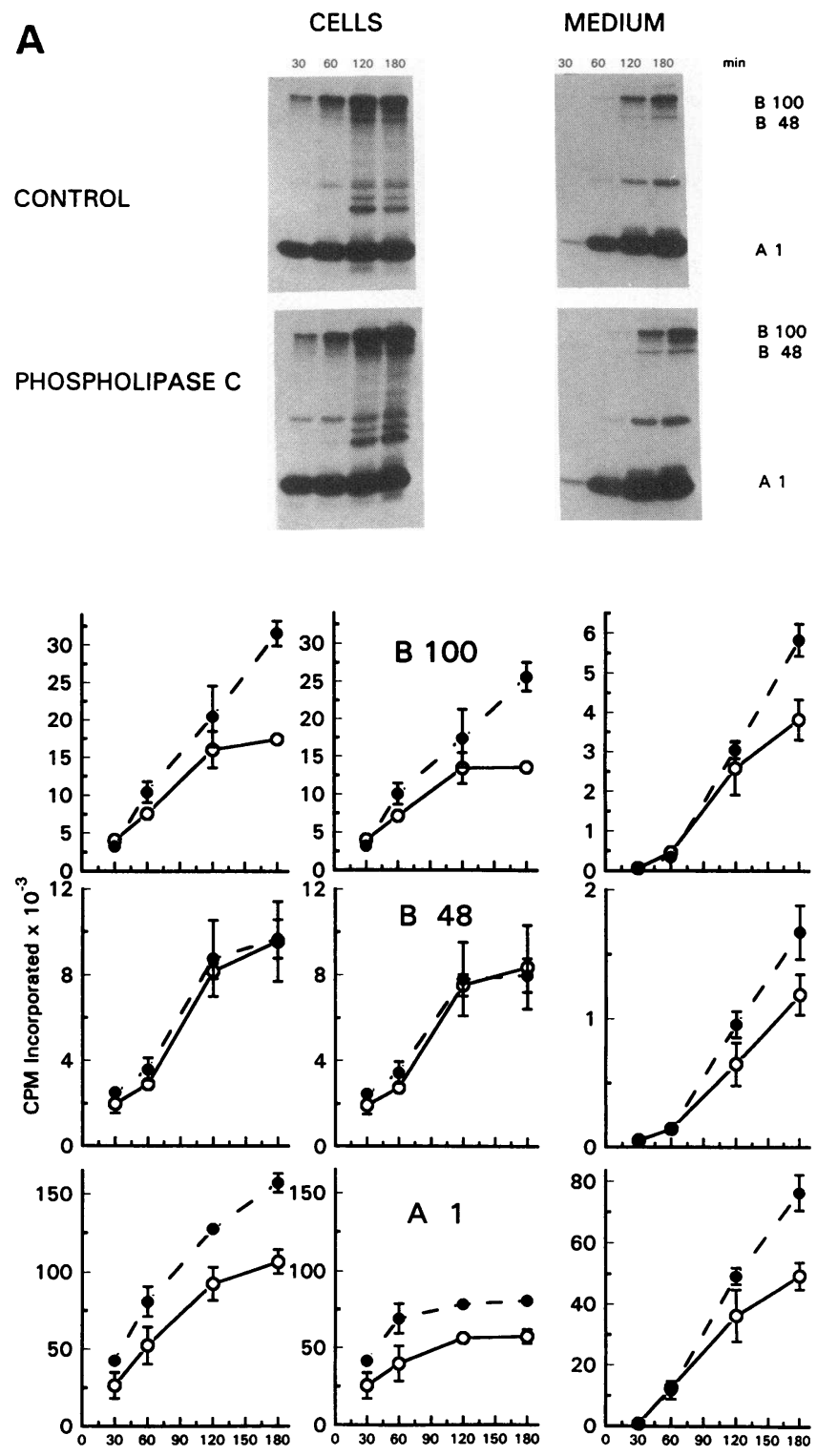

Time (min)

Figure 5. Effect of phosphatidylcholine phospholipase $\mathrm{C}$ on the incorporation of $\left[{ }^{35} \mathrm{~S}\right]$ methionine into apo $\mathrm{B}$ and apo $\mathrm{AI}$. The experiment was performed exactly as described in the legend for Fig. 3, except $200 \mathrm{mU} / \mathrm{ml}$ of phosphatidylcholine phospholipase $C$ was substituted for sphingomyelinase. This figure shows a representative autoradiogram $(A)$ and the amount of radioactivity recovered from the apoprotein bands $(B) . \circ$, control; $\bullet$, phospholipase $C$. 
synthesis and secretion of the labeled apoproteins. These data would suggest, therefore, that the inhibition of apo B secretion by sphingomyelinase cannot be explained by the general action of a phospholipase $\mathrm{C}$ on the cell membrane.

$P K C$ activity. There is recent evidence suggesting that lipid products released by the hydrolysis of membrane sphingomyelin can alter cellular biological function through the regulation of PKC activity (for review see references 11,12). To determine if sphingomyelin hydrolysis of $\mathrm{CaCo}-2$ cell membranes altered PKC activity, cells were incubated for $16 \mathrm{~h}$ with 100 $\mathrm{mU} / \mathrm{ml}$ of sphingomyelinase and PKC activity was measured (Fig. 6). Compared to the activity in control cells, membranebound $\mathrm{PKC}$ was inhibited two fold after sphingomyelin hydrolysis. PKC activity in cytosol was also decreased after sphingomyelin hydrolysis, but because of interexperimental variability, the effect was not significant.

To investigate if the inhibition of apo B secretion after sphingomyelin hydrolysis was related to the decrease observed in PKC activity, cells were incubated for $16 \mathrm{~h}$ with oleic acid attached to albumin and the phorbol ester, PMA $(1 \mu \mathrm{M})$, or the PKC inhibitor, staurosporine $(0.1 \mu \mathrm{M})$. The activity of PKC was undetectable in membranes prepared from cells incubated with the phorbol ester, and in in vitro assays containing membranes prepared from $\mathrm{CaCo}-2$ cells, $0.01 \mu \mathrm{M}$ staurosporine caused complete inhibition of PKC activity (data not shown ). The effect of PMA and staurosporine on the incorporation of $\left[{ }^{35} \mathrm{~S}\right]$ methionine into apo $\mathrm{B}$ and apo AI within cells and apoproteins secreted into the basolateral medium was determined (Fig. 7, $A$ and $B$ ). Staurosporine did not alter the incorporation of labeled methionine into cellular apo B100, apo B48, or apo AI. In contrast, the phorbol ester caused a decrease in the incorporation of label into both apoproteins. Similar to what was observed with sphingomyelinase treatment, however, both agents caused a marked decrease in the basolateral secretion of labeled apo B100 and apo B48 without markedly affecting the secretion of labeled apo AI.

Since apo B secretion was decreased under conditions in which PKC activity was inhibited, a possible relationship between PKC activity and apo B secretion was investigated. To determine if the stimulation of PKC activity would cause an increase in apo B secretion, cells were incubated for short periods with PMA or for $16 \mathrm{~h}$ with 1,2-dioctanoylglycerol, a cell permeable analog of diacylglycerol known to stimulate PKC activity. The incorporation of labeled methionine into apo B

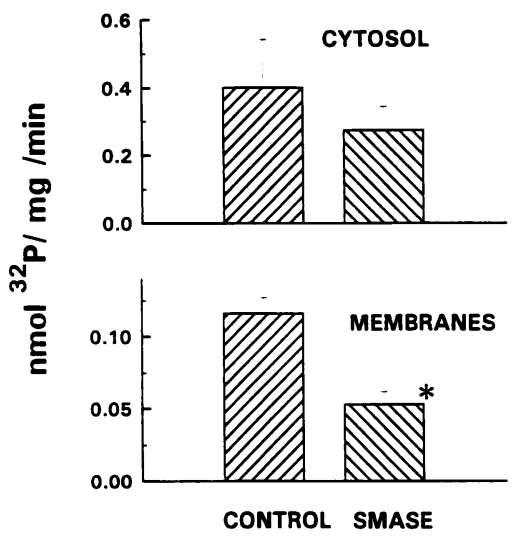

Figure 6. Effect of sphingomyelin hydrolysis on PKC activity. $\mathrm{CaCo}-2$ cells were cultured for $14 \mathrm{~d}$ on 24 well plates. On the day of the experiment, cells were washed twice with M199 and incubated for $16 \mathrm{~h}$ in M199 containing $100 \mathrm{mU} / \mathrm{ml}$ of sphingomyelinase (SMASE): Cytosol and total membrane fractions were prepared and PKC activity deter-

mined as described in Methods. The data represent the mean $\pm \mathrm{SE}$ of three separate experiments. ${ }^{*} P<0.01$ vs control.

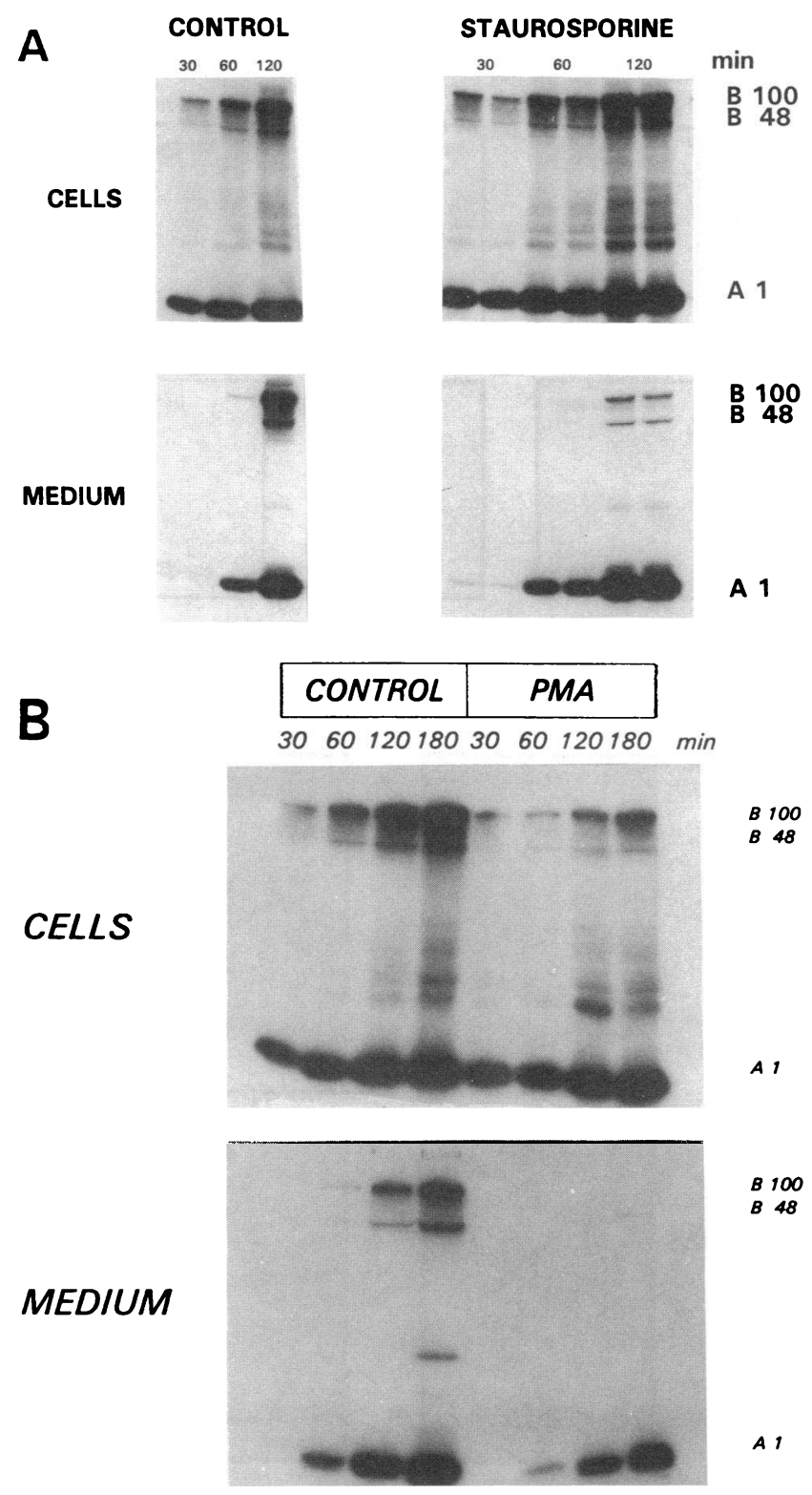

Figure 7. Effect of PMA or staurosporine on $\left[{ }^{35} \mathrm{~S}\right]$ methionine incorporation into apo $\mathrm{B}$ and apo $\mathrm{AI}$. The experiment was performed exactly as described in Fig. 3, except staurosporine $10^{-7} \mathrm{M}(A)$ or PMA $10^{-6} \mathrm{M}(B)$ was added in place of sphingomyelinase.

within cells and that secreted into the basolateral medium was then estimated (Fig. 8, $A$ and $B$ ). Diacylglycerol, at concentrations of 400 and $800 \mu \mathrm{g} / \mathrm{ml}$, did not alter the synthesis or the secretion of newly synthesized apo B. Likewise, short-term incubation with the phorbol ester did not increase the secretion of labeled apo B. In fact, there was a modest decrease in the amount secreted compared to control. Thus, although apo B secretion was decreased when cells were incubated with agents that inhibit PKC activity, the reverse was not true. Apo B secretion was not increased under conditions in which PKC activity would be stimulated.

The results, however, still do not exclude the possibility that sphingomyelin hydrolysis decreased apo B secretion by inhibiting PKC activity. To address this, cells were incubated for $16 \mathrm{~h}$ with $100 \mathrm{mU} / \mathrm{ml}$ of sphingomyelinase in the presence or ab- 

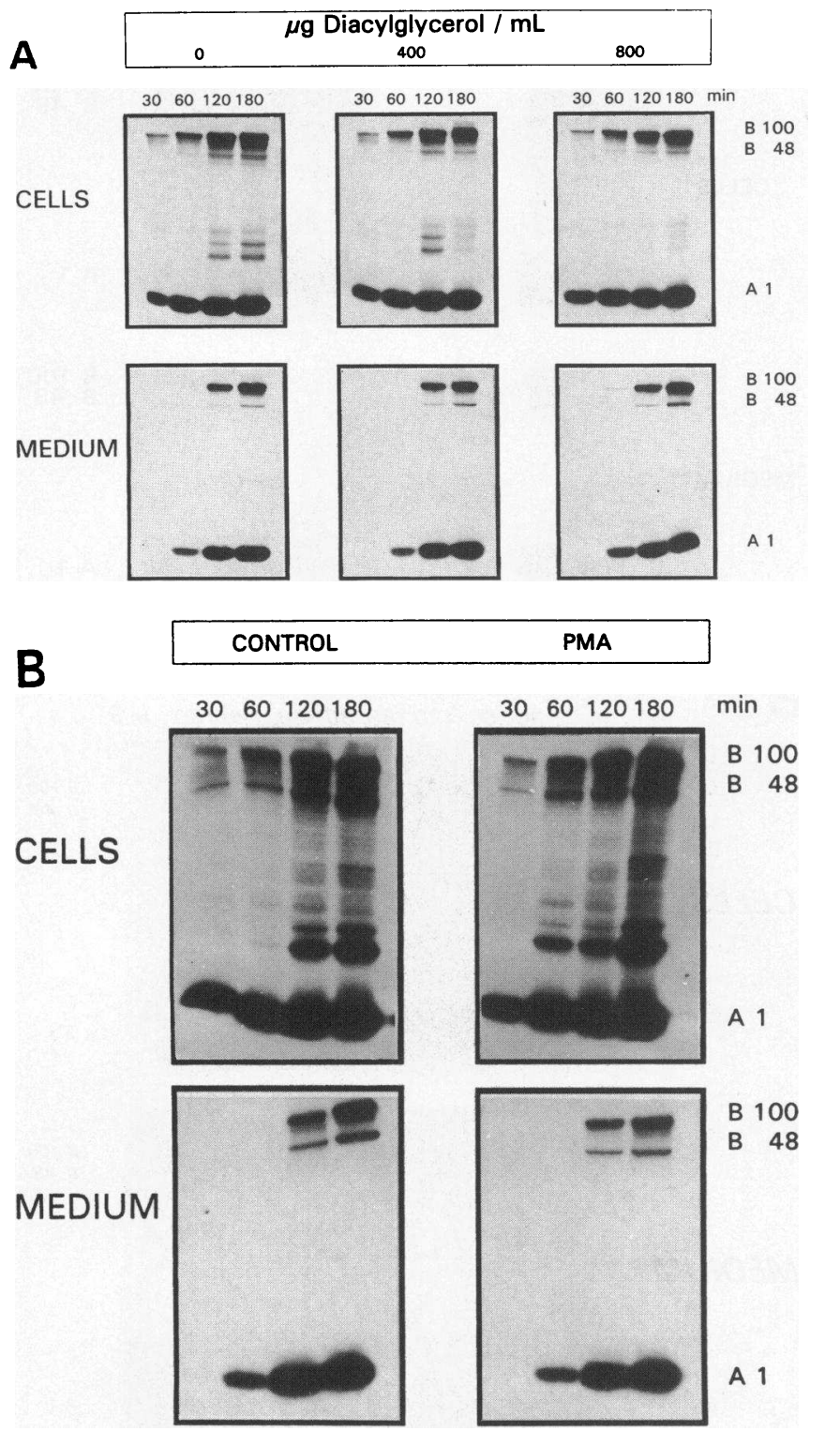

Figure 8. Effect of 1,2-dioctanoylglycerol and short-term incubation with PMA on the incorporation of $\left[{ }^{35} \mathrm{~S}\right]$ methionine into apo $\mathrm{B}$ and apo AI. $(A)$ Cells were incubated for $16 \mathrm{~h}$ in M199 containing 400 or $800 \mu \mathrm{g} / \mathrm{ml}$ of dioctanoylglycerol. The cells were washed twice and preincubated for $1 \mathrm{~h}$ in methionine-free medium. $\left[{ }^{35} \mathrm{~S}\right]$ Methionine, $100 \mu \mathrm{Ci}$, was added for $3 \mathrm{~h}$ and at the times indicated, apo B and apo AI were immunoprecipitated from the cells and basolateral media. $(B)$ In this experiment, $1 \mu$ M PMA was added at the same time as $\left[{ }^{35} \mathrm{~S}\right]$ methionine (time 0 ). The immunoprecipitated apoproteins were separated by SDS polyacrylamide gel electrophoresis. This figure depicts autoradiograms of a representative experiment from each treatment.

sence of $0.1 \mu \mathrm{M}$ staurosporine. After the incubation, the amount of apo B mass secreted into the basolateral medium and the synthesis and secretion of newly synthesized apo B were determined (Fig. 9, $A$ and $B$ ). Apo B mass within cells was modestly decreased when cells were incubated with both staurosporine and sphingomyelinase. As demonstrated above, sphingomyelinase or staurosporine alone decreased the secretion of apo B mass. Moreover, the combination of the two decreased the secretion of apo B beyond that expected for either agent

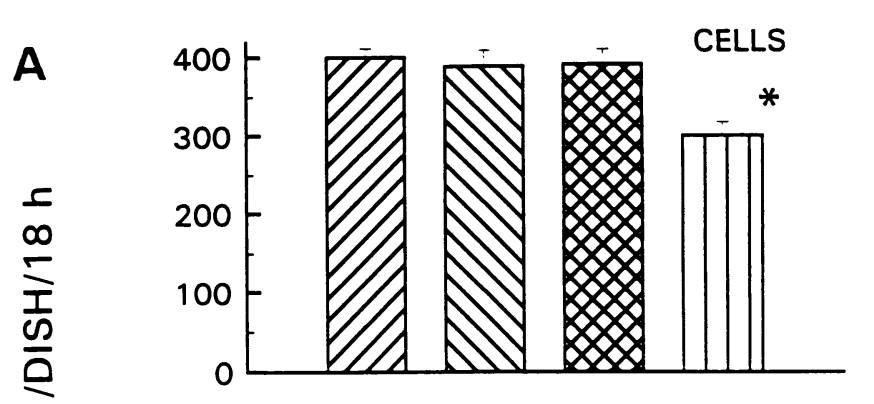

$\infty$
0
0
0
0

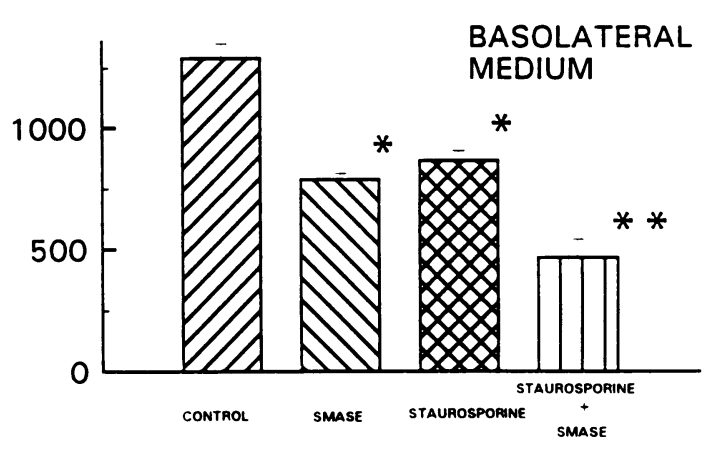

B

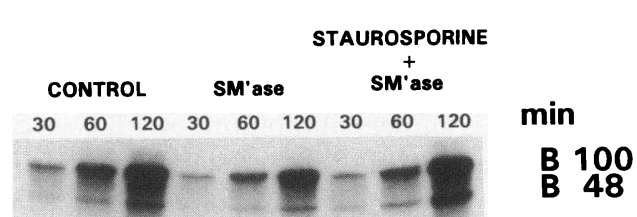

CELLS

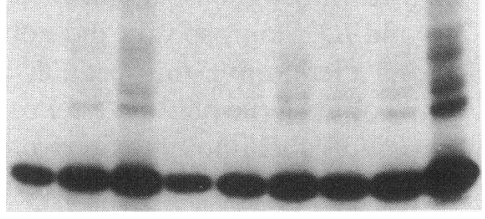

A 1

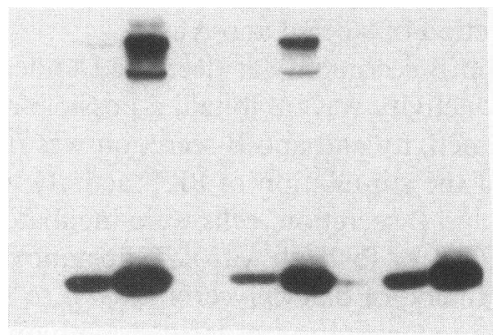

B 100
B 48

A 1

Figure 9. Effect of sphingomyelinase plus staurosporine on apo B mass secretion and the incorporation of $\left[{ }^{35} S\right]$ methionine into apo $B$ and apo AI. Cells were incubated for $16 \mathrm{~h}$ with $100 \mathrm{mU} / \mathrm{ml}$ of sphingomyelinase (SMASE) or $0.1 \mu \mathrm{M}$ staurosporine or both staurosporine and SMASE in M199 containing $1 \mathrm{mM}$ oleic acid attached to albumin $(3: 1, \mathrm{~mol} / \mathrm{mol})$. ( $A$ ) Apo B mass was estimated within cells and in the basolateral medium $(n=6) .(B)$ The incorporation of $\left[{ }^{35} \mathrm{~S}\right]$ methionine into cellular and basolateral apoproteins was estimated as described in Methods. ${ }^{*} P<0.05$ vs control. ${ }^{* *} P<0.05$ vs SMASE or staurosporine treatments.

used alone. In results shown in Fig. $9 B$, there was a modest decrease in the incorporation of labeled methionine into cellular apo B after sphingomyelin hydrolysis. The addition of staurosporine caused a modest increase in this incorporation. More importantly, however, compared to cells incubated with sphingomyelinase alone, cells incubated with sphingomyelinase and staurosporine secreted significantly less newly synthe- 
sized apo B. Apo AI secretion was not significantly altered by sphingomyelinase or sphingomyelinase and staurosporine together. The additive effects of sphingomyelinase and staurosporine on apo B secretion suggest that sphingomyelinase is acting through a mechanism that differs from that of staurosporine. Thus, the results suggest that sphingomyelin hydrolysis decreases apo B secretion by a mechanism that is independent of its effect on PKC activity.

Sphingosine and ceramide analogs. Since the above combined data made PKC an unlikely candidate to explain the mechanism for the effect of sphingomyelin hydrolysis on apo B secretion, the possibility that sphingosine or ceramide could be playing a role in apo $\mathrm{B}$ secretion was explored next. Cells were incubated for $16 \mathrm{~h}$ with sphingosine at concentrations of 50 , 100 , and $200 \mu \mathrm{M}$ and the amount of apo B mass secreted into the basolateral medium was determined ( Table II). Compared with controls, sphingosine did not alter the amount of apo B mass secreted. This was true whether sphingosine was added in an albumin solution (shown here) or in ethanol alone without the oleic acid-albumin solution (data not shown).

In contrast, when the cell-permeable analogs of ceramide, $\mathrm{C}_{2}$-Cer and $\mathrm{C}_{6}$-Cer, were added to cells in increasing concentrations, the amount of apo $B$ mass secreted into the basolateral medium was significantly decreased in a dose-dependent fashion (Fig. 10). In other experiments in which the ceramide analogs were added in ethanol alone, the trend of decreased apo B secretion remained, but the data were more variable and less convincing. The presence of albumin might increase the delivery of the ceramide analogs to the cells or active lipoprotein production might be required to cause the observed decrease in apo B mass secretion by ceramide. After sphingomyelin hydrolysis, the amount of ceramide mass that accumulated within cells was approximately twice the amount found in control cells $(3.4 \pm 0.3$ vs $1.3 \pm 0.2 \mathrm{nmol} / \mathrm{mg}$ protein, respectively, $n=9$ ).

\section{Discussion}

The results of this study clearly demonstrate that after the hydrolysis of membrane sphingomyelin, there is a significant decrease in the basolateral secretion of triacylglycerols and apo B by cultured human intestinal cells. Several possible mechanisms to explain this observation were explored. Since most sphingomyelin is localized to the plasma membrane of cells, it could be argued that the loss of this structural phospholipid from the membrane could have altered its physical properties to the extent that cellular secretion was disrupted. This is an

Table II. Effect of Sphingosine on Apo B Mass Secretion

\begin{tabular}{ccc}
\hline Sphingosine & Cells & Basolateral medium \\
\hline & & ng apo B/dish/18 h \\
0 & $67 \pm 2$ & $442 \pm 5$ \\
50 & $64 \pm 3$ & $442 \pm 14$ \\
100 & $74 \pm 3$ & $449 \pm 21$ \\
200 & $75 \pm 3$ & $461 \pm 20$
\end{tabular}

Cells were incubated for $16 \mathrm{~h}$ in M199 containing $1 \mathrm{mM}$ oleic acid attached to albumin (4:1, mol:mol) and increasing concentrations of sphingosine. The values for apo B represent the mean \pm SE of six separate experiments.

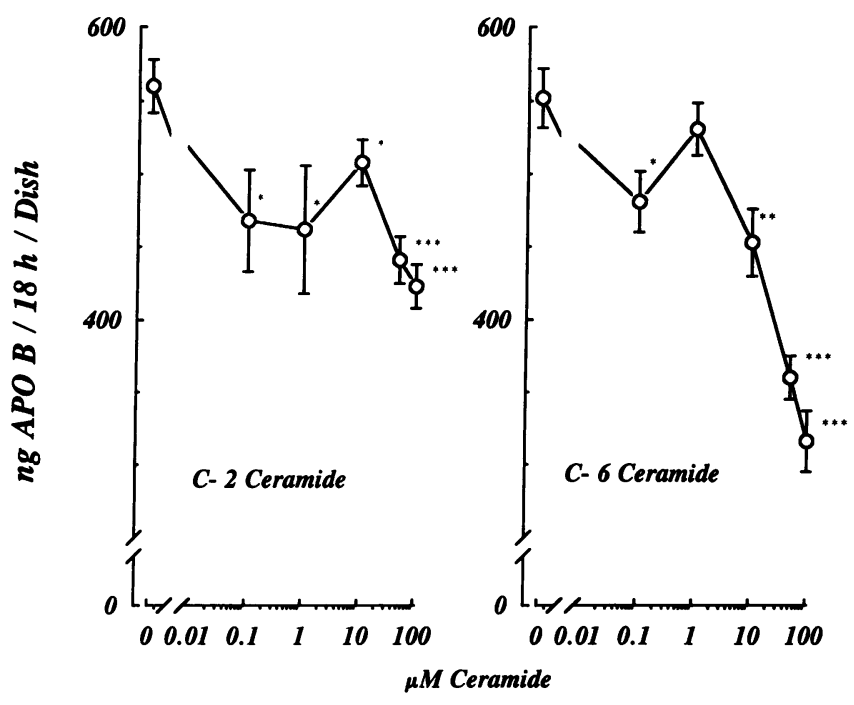

Figure 10. Effect of $\mathrm{C}_{2}$-Cer and $\mathrm{C}_{6}$-Cer on the secretion of apo $\mathrm{B}$ mass. Cells were incubated for $16 \mathrm{~h}$ with increasing concentrations of $\mathrm{C}_{2}-\mathrm{Cer}$ or $\mathrm{C}_{6}$-Cer in M199 containing $1 \mathrm{mM}$ oleic acid attached to albumin (4:1, mol:mol). The ceramide analogs were added to the albuminoleic acid mixture in ethanol ( $0.3 \%$ of total volume). Control dishes received the same amount of ethanol but without the ceramides. The amount of apo B mass secreted into the basolateral medium was estimated as described in Methods. The data represent the means \pm SE of eight transwells from three individual experiments. Assays for apo $B$ mass estimation by ELISA were performed in triplicate. ${ }^{*} P<0.05$ vs control. ${ }^{* *} P<0.01$ vs control. ${ }^{* * *} P<0.001$ vs control.

unlikely explanation for the decrease observed in apo B secretion, however, as the basolateral secretion of newly synthesized TCA-precipitable proteins, apo AI, and phospholipids were not significantly altered after sphingomyelin hydrolysis. Although physical properties of the apical membrane are likely to be altered after sphingomyelin hydrolysis, other mechanisms appear to be involved to explain a decrease in the secretion of apo $B$ and triacylglycerol from the basolateral membrane.

It has been demonstrated that cholesterol synthesis is decreased and esterification is increased within cells after sphingomyelin hydrolysis as cholesterol leaves the plasma membrane and enters intracellular pools $(6,7,16)$. It is possible that this influx of cholesterol with its accompanying changes in cholesterol metabolism could lead to a decrease in apo B secretion. We and others, however, have found little evidence to suggest that a change in cholesterol flux regulates apo B secretion. Similar to what is observed after sphingomyelin hydrolysis, the addition of 25-hydroxycholesterol to cells leads to a decrease in cholesterol synthesis and an increase in cholesterol esterification (31, 32). In Hep G2 cells, 25-hydroxycholesterol was found to either increase, or have no effect on, apo B secretion (33). We have observed that neither native cholesterol nor 25-hydroxycholesterol alters the rate of synthesis or secretion of apo B in CaCo-2 cells (Field, F. J., E. Born, H. Chen, and S. N. Mathur. 1994. Regulation of apolipoprotein b secretion by biliary lipids in CaCo-2 cells. J. Lipid Res. In press. ). Thus, the decrease observed in apo B secretion after sphingomyelin hydrolysis is likely unrelated to the influx of cholesterol or the subsequent changes in cholesterol metabolism.

In our previous study using labeled choline to estimate the amount of cellular sphingomyelin and phosphatidylcholine remaining after sphingomyelin hydrolysis, $100 \mathrm{mU} / \mathrm{ml}$ of sphin- 
gomyelinase (the highest concentration used in this study) did not alter the amount of cellular phosphatidylcholine (16). The present data substantiated our previous results. The amount of phosphatidylcholine mass remaining in cells incubated with sphingomyelinase was not significantly different from controls. This was important to readdress as the significance of phosphatidylcholine in the normal assembly and secretion of triacylglycerol-rich lipoproteins has been demonstrated (34). However, loss of cellular phosphatidylcholine cannot be implicated as a mechanism for the decrease in apo B secretion after sphingomyelin hydrolysis in the present study. Moreover, the lack of effect of phosphatidylcholine-specific phospholipase $C$ on apo B secretion provides further support that neither the loss of phosphatidylcholine mass nor the action of a phospholipase $\mathrm{C}$ enzyme play a role in the regulation of apo B secretion after sphingomyelin hydrolysis.

The amount of phosphatidylethanolamine remaining in cells after sphingomyelin hydrolysis, however, was less than in control cells. In hepatocytes, the methylation of phosphatidylethanolamine can substitute for the synthesis of phosphatidylcholine when the CDP-choline pathway is blocked (35). This could be important for triacylglycerol-rich lipoprotein synthesis in choline-deficient animals in which the amount of phosphatidylcholine is severely limiting. As stated above, however, phosphatidylcholine is not limiting in intestinal cells incubated with sphingomyelinase. Although it cannot be excluded with certainty that a $20 \%$ decrease in phosphatidylethanolamine could cause the inhibition of apo B secretion observed here, to our knowledge there is no evidence to support the notion that phosphatidylethanolamine is important for the secretion of triacylglycerol-rich lipoproteins.

Ceramide and diacylglycerol are products that are generated during the hydrolysis of sphingomyelin $(36,37)$. Ceramide can be further metabolized to sphingosine by deacylation. All three of these products have been implicated as biological mediators of the signal transduction pathway $(11,12)$. Sphingosine is a recognized inhibitor of PKC, leading to the suppression of several biological events mediated by this important kinase (13). Previous studies have documented a decrease in PKC activity and the regulation of PKC-mediated cellular events after sphingomyelin hydrolysis (15). Since PKC activity was decreased by $50 \%$ in membranes prepared from cells incubated with sphingomyelinase, the generation of sphingosine was considered as a potential mechanism to explain the decrease in PKC activity. Moreover, the possible involvement of PKC in the secretion of apo B was postulated (38).

The present results, however, did not confirm this relationship. The addition of exogenous sphingosine, in concentrations that would be expected to inhibit PKC activity, did not alter apo B secretion. Although inhibiting PKC activity with staurosporine or depleting cells of PKC by long-term incubation with phorbol ester decreased apo B secretion as did sphingomyelin hydrolysis, it cannot be said with certainty that these two events are related. Like phorbol esters, staurosporine can have marked effects on cell growth and differentiation (39). Because apo B secretion by cultured intestinal cells is highly dependent upon their differentiation and maturity, agents that can alter these processes will likely interfere with apo B secretion (40, 41). Moreover, agents that stimulate PKC activity, such as 1,2-dioctanoylglycerol and short-term incubation with PMA, did not alter apo B secretion. In addition, adding to cells phosphatidylcholine-specific phospholipase $C$, which would in- crease the endogenous levels of 1,2-diacylglycerol, did not significantly alter the secretion of apo B compared to the secretion of apo AI. Lastly and perhaps most convincingly, the effect of sphingomyelinase and staurosporine together on the secretion of immunoreactive and newly synthesized apo B was additive, suggesting that sphingomyelinase was acting through a mechanism that differed from that of staurosporine. Although these results do not completely exclude the possibility that apo B secretion is decreased by the inhibition of PKC, the data favor the notion that sphingomyelin hydrolysis decreases apo B secretion independently of its effect on PKC activity.

Ceramide levels were elevated twofold in cells after sphingomyelin hydrolysis. This metabolite of sphingomyelin catabolism has been postulated to play an important role in cellular proliferation and differentiation $(20,42,43)$. Using cell-permeable analogs of ceramide, a significant decrease in the secretion of immunoreactive apo $\mathrm{B}$ by cells incubated with $\mathrm{C}_{6}$-Cer or $\mathrm{C}_{2}$-Cer was observed. Why ceramide accumulation within the cell should decrease apo B secretion is unknown. Pagano et al. (44) have demonstrated that both exogenously added ceramide and ceramide that is generated intracellularly after sphingomyelin hydrolysis accumulate within the Golgi apparatus. Recent data from these investigators have shown that cell permeable analogs of ceramide disrupt the trafficking of secretory GPs in CHO cells (45). Since our results suggest that the predominate effect of sphingomyelin hydrolysis is the disruption of apo B secretion, ceramide that accumulates within the Golgi apparatus could potentially interfere with apo B secretion. Studies are in progress to address this question.

\section{Acknowledgments}

We are grateful for the expert technical assistance of Dr. Satoshi Kubodera in performing the PKC assays and to Mrs. Joan Ockenfels for typing the manuscript.

This work was supported by the Veterans Administration, HL 49264 (F. J. Field) and HL 42377 FIRST Award (B. Dixon).

\section{References}

1. Lange, Y., M. H. Swaisgood, B. V. Ramos, and T. L. Steck. 1989. Plasma membranes contain half the phospholipid and $90 \%$ of the cholesterol and sphingomyelin in cultured human fibroblasts. J. Biol. Chem. 264:3786-3793.

2. Yechiel, E., Y. I. Henis, and Y. Barenholz. 1986. Aging of rat heart fibroblasts: relationship between lipid composition, membrane organization, and biological properties. Biochim. Biophys. Acta. 859:95-104.

3. Hostetler, K. Y., B. D. Zenner, and H. P. Morris. 1979. Phospholipid content of mitochondrial and microsomal membranes from Morris hepatomas of varying growth rates. Cancer Res. 39:2978-2983.

4. Williams, R. D., D. S. Sgoutas, and G. S. Zaatari. 1986. Enzymology of long-chain base synthesis by aorta: induction of serine palmitoyltransferase activity in rabbit aorta during atherogenesis. J. Lipid Res. 27:763-770.

5. Lange, Y., J. S. D'Alessandro, and D. M. Small. 1979. The affinity of cholesterol for phosphatidylcholine and sphingomyelin. Biochim. Biophys. Acta. 556:388-398

6. Slotte, J. P., and E. L. Bierman. 1988. Depletion of plasma membrane sphingomyelin rapidly alters the distribution of cholesterol between plasma membranes and intracellular cholesterol pools in cultured fibroblasts. Biochem. J. 250:653-658.

7. Gupta, A. K., and H. Rudney. 1991. Plasma membrane sphingomyelin and the regulation of HMG-CoA reductase activity and cholesterol biosynthesis in cell cultures. J. Lipid Res. 32:125-136.

8. Pentchev, P. G., H. S. Kruth, M. E. Comly, J. D. Butler, M. T. Vanier, D. A Wenger, and S. Patel. 1986. Type C Niemann-Pick disease. J. Biol. Chem. 261:16775-16780.

9. Liscum, L., and J. R. Faust. 1987. Low density lipoprotein (LDL)-mediated suppression of cholesterol synthesis and LDL uptake is defective in Niemann-Pick type C fibroblasts. J. Biol. Chem. 262:17002-17008.

10. Sidhu, H. S., S. A. R. Rastogi, D. M. Byers, H. W. Cook, F. B. St. C. 
Palmer, and M. W. Spence. 1992. Cultured fibroblasts from patients with Niemann-Pick disease type $C$ and type $D$ exhibit distinct defects in cholesterol esterification. Biochim. Biophys. Acta. 1124:29-35.

11. Hannun, Y. A., and R. M. Bell. 1989. Functions of sphingolipids and sphingolipid breakdown products in cellular regulation. Science (Wash. DC). 243:500-507.

12. Kolesnick, R. N. 1991. Sphingomyelin and derivatives as cellular signals. Prog. Lipid Res. 30:1-38.

13. Hannun, Y. A., C. R. Loomis, A. H. Merrill, Jr., and R. M. Bell. 1986. Sphingosine inhibition of protein kinase $C$ activity and of phorbol dibutyrate binding in vitro and in human platelets. J. Biol. Chem. 261:12604-12609.

14. Goldkorn, T., K. A. Dressler, J. Muindi, N. S. Radin, J. Mendelsohn, D. Menaldino, D. Liotta, and R. N. Kolesnick. 1991. Ceramide stimulates epidermal growth factor receptor phosphorylation in A431 human epidermoid carcinoma cells. J. Biol. Chem. 266:16092-16097.

15. Kolesnick, R. N., and S. Clegg. 1988. 1,2-diacylglycerols, but not phorbol esters, activate a potential inhibitory pathway for protein kinase $\mathrm{C}$ in $\mathrm{GH}_{3}$ pituitary cells. J. Biol. Chem. 263:6534-6537.

16. Chen, H., E. Born, S. N. Mathur, F. C. Johlin, and F. J. Field. 1992. Sphingomyelin content of intestinal cell membranes regulates cholesterol absorption: evidence for pancreatic and intestinal cell sphingomyelinase activity. Biochem. J. 286:771-777.

17. Field, F. J., E. Albright, and S. Mathur. 1991. Inhibition of acylcoenzyme A: cholesterol acyltransferase activity by PD128042. Effect on cholesterol metabolism and secretion in CaCo-2 cells. Lipids. 26:1-8.

18. Murthy, S., E. Albright, S. N. Mathur, N. O. Davidson, and F. J. Field. 1992. Apolipoprotein B mRNA abundance is decreased by eicosapentaenoic acid in CaCo-2 cells: effect on the synthesis and secretion of apolipoprotein B. Arterioscler. Thromb. 12:691-700.

19. Preiss, J. E., C. R. Loomis, R. M. Bell, and J. E. Niedel. 1987. Quantitative measurement of sn-1,2-diacylglycerols. Methods Enzymol. 141:294-300.

20. Okazaki, T., A. Bielawska, R. M. Bell, and Y. A. Hannun. 1990. Role of ceramide as a lipid mediator of $1 \alpha, 25$-dihydroxyvitamin $\mathrm{D}_{3}$-induced HL-60 cell differentiation. J. Biol. Chem. 265:15823-15831.

21. Doucet, J., B. J. Murphy, and B. S. Tuana. 1990. Modification of a discontinuous and highly porous sodium dodecyl sulfate polyacrylamide gel system for minigel electrophoresis. Anal. Biochem. 190:209-211.

22. Chomczynski, P., and N. Sacchi. 1987. Single-step method of RNA isolation by acid guanidinium thiocyanate-phenol-chloroform extraction. Anal. Biochem. 162:156-159.

23. Feinberg, A. P., and B. Vogelstein. 1983. A technique of radiolabeling DNA restriction endonuclease fragments to high specific activity. Anal. Biochem. 132:6-13.

24. Dixon, B. S., R. Breckon, C. Burke, and R. J. Anderson. 1988. Phorbol esters inhibit adenylate cyclase activity in cultured cortical collecting tubular cells. Am. J. Physiol. 254:C183-C191.

25. Bradford, M. M. 1976. A rapid and sensitive method for the quantitation of microgram quantities of protein utilizing the principle of protein-dye binding. Anal. Biochem. 72:248-254.

26. Lowry, O. H., N. J. Rosebrough, A. L. Farr, and R. J. Randall. 1951. Protein measurements with the Folin phenol reagent. J. Biol. Chem. 193:265275.

27. Murthy, S., E. Albright, S. N. Mathur, and F. J. Field. 1990. Effect of eicosapentaenoic acid on triacylglycerol transport. Biochim. Biophys. Acta. 1045:147-155.

28. Chalvardjian, A., and E. Rudnicki. 1970. Determination of lipid phosphorous in nanomolar range. Anal. Biochem. 36:225-226.

29. Sparks, J. D., and C. E. Sparks. 1990. Insulin modulation of hepatic synthesis and secretion of apolipoprotein B by rat hepatocytes. J. Biol. Chem. 265:8854-8862.

30. Dixon, J. L., S. Furukawa, and H. N. Ginsberg. 1991. Oleate stimulates secretion of apolipoprotein B-containing lipoproteins from Hep G2 cells by inhibiting early intracellular degradation of apolipoprotein B. J. Biol. Chem. 266:5080-5086.

31. Field, F. J., and S. N. Mathur. 1983. Regulation of acyl-CoA: cholesterol acyltransferase by 25 -hydroxycholesterol in rabbit intestinal microsomes and absorptive cells. J. Lipid Res. 24:1049-1059.

32. Kandutsch, A. A., and H. W. Chen. 1975. Regulation of sterol synthesis in cultured cells by oxygenated derivatives of cholesterol. Cell Physiol. 85:415-424.

33. Dashti, N. 1992. The effect of low density lipoproteins, cholesterol, and 25-hydroxycholesterol on apolipoprotein B gene expression in Hep G2 cells. $J$. Biol. Chem. 267:7160-7169.

34. Yao, Z., and D. E. Vance. 1988. The active synthesis of phosphatidylcholine is required for very low density lipoprotein secretion from rat hepatocytes. $J$. Biol. Chem. 263:2998-3004.

35. Yao, Z., and D. E. Vance. 1989. Head group specificity in the requirement of phosphatidylcholine biosynthesis for very low density lipoprotein secretion from cultured hepatocytes. J. Biol. Chem. 264:11373-11380.

36. Koval, M., and R. E. Pagano. 1991. Intracellular transport and metabolism of sphingomyelin. Biochim. Biophys. Acta. 1082:113-125.

37. Hampton, R. Y., and O. H. Morand. 1989. Sphingomyelin synthase and PKC activation. Science (Wash. DC). 246:1050.

38. Field, F. J., H. Chen, E. Born, B. Dixon, and S. N. Mathur. 1993. Sphingomyelin hydrolysis suppresses triglyceride-rich lipoprotein secretion by $\mathrm{CaCo}-2$ cells: role of protein kinase C. Clin. Res. 41:160A.

39. Tamaoki, T., H. Nomoto, I. Takahashi, Y. Kato, M. Morimoto, and F. Tomita. 1986. Staurosporine, a potent inhibitor of phospholipid $/ \mathrm{Ca}^{++}$dependent protein kinase. Biochem. Biophys. Res. Commun. 135:397-402.

40. Dashti, N., E. A. Smith, and P. Alaupovic. 1990. Increased production of apolipoprotein B and its lipoproteins by oleic acid in CaCo-2 cells. J. Lipid Res. 31:113-123.

41. Moberly, J. B., T. G. Cole, D. H. Alpers, and G. Schonfeld. 1990. Oleic acid stimulation of apolipoprotein B secretion from Hep G2 and CaCo-2 cells occurs posttranscriptionally. Biochim. Biophys. Acta. 1042:70-80.

42. Dobrowsky, R. T., and Y. A. Hannun. 1992. Ceramide stimulates a cytosolic protein phosphatase. J. Biol. Chem. 267:5048-5051.

43. Olivera, A., N. E. Buckley, and S. Spiegel. 1992. Sphingomyelinase and cell-permeable ceramide analogs stimulate cellular proliferation in quiescent Swiss 3T3 fibroblasts. J. Biol. Chem. 267:26121-26127.

44. Pagano, R. E., O. C. Martin, H. C. Kang, and R. P. Haugland. 1991. A novel fluorescent ceramide analogue for studying membrane traffic in anima cells: accumulation at the Golgi apparatus results in altered spectral properties of the sphingolipid precursor. J. Cell Biol. 113:1267-1279.

45. Rosenwald, A. G., and R. E. Pagano. 1993. Inhibition of glycoprotein traffic through the secretory pathway by ceramide. J. Biol. Chem. 268:45774579 . 